\title{
Review of the Routledge International Handbook of Rural Criminology, Joseph F. Donnermeyer (Editor)
}

\author{
Routledge, 2016, 426 pages \\ ISBN: 9781315755885 \\ Review by Ragnhild Sollund \\ University of Oslo \\ Department of Criminology and Sociology of Law \\ ragnhild.sollund@JUS.UIO.NO
}

\section{Introduction}

I will start by congratulating Joseph Donnermeyer with compiling this impressive book and thus firmly positioning rural criminology in criminology. The chapters span a large range of locations all over the world; over a generous number of topics; over of a diversity of crimes and how they are addressed; as well as over the criminalizing of rural people and their protests, including of indigenous groups.

The book contains 42 chapters, of which the first is an introduction to the field and the last is about lesson that can be learned, both written by the editor, who has also written a helpful introduction to each of the five sections.

In the introduction to the handbook, Donnermeyer addresses the urban bias of criminology, also pointed to by Paul Stretesky and Michael Lynch (2014) and Nils Christie (1975) when exemplifying that what is regarded as the 'genuine crime' thus meriting criminological interest is crime committed on the cities' streets by young male offenders, such as street robberies. Donnermeyer sees words as 'fixed', 'narrow-mindedness', 'partiality', 'warped' and 'skewed' as good definers of criminology's past relationship to rural criminology, and also that this ignoring of rural crimes pertains to a collective criminological conscience where urban crimes have no room. He argues: "Places are diverse and without diversity, comparative analysis, both statistical and qualitative, cannot be accomplished. All sciences require variation" (Donnermeyer, p. 2).

Further, while urbanization all over the world increases with population growth, population growth is not limited to cities, thus, as he further argues, throughout this century the rural population will number in the billions, and the places where they live will number in the tens of millions. Donnermeyer thus asks the questions: How did this urban bias arise, and why is it only now, in the middle of the second decade of the $21^{\text {st }}$ century that a Handbook of this type is finally being published?

Donnermeyer also convincingly provides the answers: The collective urban focus of mainstream criminology is connected to the Chicago school and its impact, not only in the 
US, but also in other places of the world, such as in Australia, Canada, and Great Britain, and as I have seen through my criminological studies, in Norway. Social disorganization as this is viewed through the lenses of the Chicago school thus became criminology per se.

This does not mean that rural criminology was totally absent, and it was also linked to rural sociology, but which was a field with far less impact on criminology than sociology generally. Donnermeyer himself also greatly contributed to the few but over the years increasing events and publications and thus the development of the field.

Donnermeyer identifies three stages in the development of rural criminology: The first, up to the mid 1970's was scattered and atheoretical. The second he characterizes as a "blip on the radar...because it too failed to create a sustained scholarly focus on rural crime" (Donnermeyer, p. 4). However, in this era, there was a larger volume of published research and it included a larger variety of topics, from violence to rural policing. Second, the work from this era was more theoretical, borrowing particularly from sociological disorganization theory.

The third era, which we see today, started according to Donnermeyer with the publication of the first edition of Crime and Policing in Rural and Small-Town America by Ralph Weisheit, David Falcone and L. Edward Wells in 1996. The book provided a thorough synthesis of the rural crime literature in the US on crime, policing, jails, and other parts of the criminal justice system. This last era coincided with the rapid growth of the field called green criminology, and this intersection of green criminology and rural criminology will be the main topic of this review, since I identify myself within this field.

As mentioned the book covers a lot of different topics, many of which could also have figured in an edited collection of green criminology, such as animal abuse and wildlife crimes. It also covers the ways in which people, including indigenous groups, suffer from inequalities in comparisons with the urban centers, including discrimination and racism. Further, it appears that living in a rural area affects the ways in which criminalized acts such as drug abuse have dimensions that cannot be found in a similar way in cities. As is found in green criminology (e.g. White ,2002 and Stretesky et al, 2013), profit motives entail exploitation and abuse, not only of animals whether farm animals or wildlife, but also of workers, something pointing to the entanglement of different forms of oppression and discrimination (e.g. Nibert, 2003; 2012). As exemplified in this book, such patterns of discrimination concern not only ethno-and phenotypical features, gender, species and class, but also the rural by the urban.

Despite Donnermeyer stating that he would have liked to include more localities into the research, and thus make it even more global in scope (e.g. Latin America is lacking), the book still has an asset in bringing cases and scholars from so many different places of the earth together, thus pointing at commonalities in rural criminology. 


\section{Rural Criminology and Green Criminology: Lovers or Just Friends?}

In what follows I will principally concentrate on the green criminology of the rural criminology handbook, implicitly exploring this intersection. Can green criminology and rural criminology share the same bed? If yea, is the marriage mutually beneficial or the opposite? An important question is, I think; what distinguishes green criminology and rural criminology when the latter is focusing on environmental crimes and harms, including those directed at nonhuman animals? It is must be stated though, that by green criminology I understand a non-anthropocentric approach (Beirne \& South, 2007; White, 2013) including the interests not only of humans, but also those of nonhuman animals and ecosystems, envisioning that one day hopefully will come that nonhuman animals' lives matter no less than humans'.

Donnermeyer emphasizes the close relation between green criminology and rural criminology, when saying: "Without understanding the rural, green criminological scholarship is nearly impossible, and without addressing issues related to environmental crime and harms, rural criminology loses a great deal of its significance” (p. 285). Although I don't reject the statement, it still leaves me puzzled, because it leaves the question open if there are any natural borders between green criminology and rural criminology, and in that case what should define them? Or shall we be content that one may lend support to the other and that there are in reality no fundamental divide, like when Donnermeyer says rural criminology so far has benefitted more from green criminology than the opposite? What perspectives have rural criminology developed that are important for green criminology, not the least theoretically, will not be part of this review, but is nonetheless an important question to ask in relation to these tightly intertwined sub-disciplines of criminology. Should they go separate ways, or become even more intimately related?

To explore the intersection between green and rural criminology, I will go briefly through the chapters that are placed in section 5 of the book - The Intersection of Rural and Green Criminologies - while I apologize for not covering the entire handbook. I appreciate for example that chapter 14, about the abuse of factory farm animals could also have been defined within green criminology becuase it could have been discussed in relation to treadmill of production theory (Stretesky et al 2013) since much abuse of farm animals is caused by economic pressure, and as a non speciesist criminology (e.g. Beirne, 1999; 2007; Sollund 2011; White 2013). The author also references green criminology sources. The chapter's author, Jerret Lovell questions whether the factory farm and slaughterhouse are criminogenic arenas. Animal abuse in factory farming (and in other arenas such as in research experiments) as well as the categorizing of animals facilitating animal abuse have been discussed by Simon Hallsworth (2008), Tanya Wyatt (2014), and Sollund (2008) previously. 


\section{Review of green criminology chapters (or are they rural criminology chapters?)}

\section{Chapter 28: Fractured Earth, Forced Labour: A Green Criminological Analysis of Rights and the Exploitation of Landscapes and Workers in Rural Contexts}

The well-known green criminologists, Avi Brisman, Bill McClanahan and Nigel South, endeavors "to advance both green and rural criminologies, and the links between them." The chapter starts by defining the concept of environmental rights, through which non anthropocenteredness - an important feature of much green criminology (e.g. White 2013, Brisman 2014. Sollund 20133) - also is clearly visible, however the authors state that in this chapter they will keep in mind the anthropocentric understanding of environmental rights, rather than the rights of ecosystems or animals. Perhaps in this way, do they also define this work more in line with rural criminology? Following the introduction comes a legal clarification of what pertains to $1^{\text {st }}, 2^{\text {nd }}$ and $3^{\text {rd }}$ generation of human rights, or human environmental rights, the third category may be seen in perspective of intergenerational justice and horizon scanning, as these are conceptualized by Rob White (e.g. 2011, 2013). After the theoretical outline Brisman, McClanahan and South proceed to their first empirical case, which is the extremely environmentally damaging horizontal fracturing (or "fracking") a method of natural gas extraction and its consequences for environmental rights in the rural areas where this takes place. The environmental impacts of fracking include increases in water pollution, increased risk of earthquakes, and heightened air pollution. The authors thus notice that each of these effects can be understood as a fundamental violation of ecological rights, but as they have said initially, their focus remains on the anthropocentric perspective, thus environmental human rights.

One of the concerns is the effect fracking has on water supplies, which may result in conflict between groups. In addition to the damaging effects on human health of fracking, this kind of enterprise also has social costs as the areas where fracking takes place may have been socially and economically disadvantaged to begin with, and cannot cope with the boom of the industry that causes conventional crime and social unrest. The consequences of fracking are not only destructive for human health and wellbeing; they also totally destroy the landscape and thus future revenue from tourism. Interestingly, when clarifying how fracking breaches with human environmental rights, the authors also return to the rights of the environment, of the biosphere, and ecological rights, here specified as of the animals living in the areas where the fracking takes place, including endangered species and domesticated animals. In this sense we could also say fracking breaches not only ecological rights but with species justice.

Without doing so, specifically, it is still as though the authors cannot hold back from applying a broader rights -and jurist perspective than what they initially say they will, thus remaining with a green criminology more than a rural criminology approach. This I appreciate. Had this been a green criminology publication, perhaps this would have been further developed.

The second empirical case concerns human trafficking and forced labour in agriculture, 
showing how this takes place in various countries and is also partly encouraged by the structure of modern agriculture in neoliberal societies. As they say: "Paying suppliers fiercely low prices, demanding goods too quickly or on short notice, and chronically delaying payments all foster reliance on exploited labour, including unprotected agency workers, as well as forced, bonded, or child labour." In the conclusion, it is emphasized that environmental human rights may actually impact negatively on the environment, such as the right to food which may cause environmental destruction through food production. The chapter as I see it is a valuable contribution to the anthology, with an overall green criminology perspective. Although agriculture and fracking take place in rural areas, is this single criterion enough to make it rural criminology?

\section{Chapter 29: Re-conceptualising folk crime in rural contexts}

This chapter was written by Rob White, and it addresses offences that are generally perceived by perpetrators and other members of their community as not being particularly criminal, offensive, harmful or dangerous. White deals here specifically with folk crime in a rural context and in particular those crimes that in some ways pertain to the environment. Conservation policies and regulations have often been the cause for the reconceptualization of previously socially and legally accepted practices to be redefined as crime: hunting or fishing has been redefined as poaching, foraging as trespassing, the setting of fires as arson, and the cutting of trees as timber theft. When White cites von Essen (2016) claiming that hunting in Scandinavia has been criminalized and turned into subculture, this is a simplification, at least in the Norwegian context, which is not very different from the Swedish. The population of hunters in Norway is increasing and also includes women; in fact, it has turned into an urban sport which for example has led the heavily hunted grouse to be a vulnerable species. Usually hunters have killed 500,000 grouse in the annually hunt, the last year's hunt was reduced to 150,000 and the species is now on the IUCN red list. The same is the situation with hare, while elks are in abundance and hunting them is spreading to different social layers of society (Bye, 2003). The reason for the abundance is the killing of endangered large carnivores, for example a decision was made in the fall 2016 , that $70 \%$ of the Norwegian wolves counting approximately 67 wolves should be shot, 11000 hunters had registered to participate in the massacre. The decision was later overruled by the Minster of environment and climate, but the last word is unlikely said (see Sollund, 2017b for discussion). Nonetheless, depending on how to define subculture, what can be confirmed in the Norwegian context is that hunting for sport is an accepted leisure activity, more than the activity of a subculture living on the outskirt of the general population; rather they share common 'values'.

From taking the perspective of the humans who cannot any longer continue their ordinary activities because these have been criminalized, or continuing them and thus being ascribed as local heroes, an apparent green criminology jump appears to a green criminology species justice approach; namely that introduced by Piers Beirne (2014) who suggested all crimes against animals could be named theriocide. White's concern is the animals in rural factory farming, and also the impact factory harming has on free animals that are considered a pest because they in some way threaten the factory farms such as, in Australia, feral cats, wild 
dogs, foxes, feral goats, feral pigs, feral horses, rabbits, donkeys, camels, cattle, buffalo, and rabbits. Farmers have long been given the "green light" to kill animals deemed to be feral and this too, is part of longstanding rural tradition. White keeps his green criminology species justice approach in the chapter through a continuation of a focus on the harms done to animals, as well as in applying references to green criminology authors to support it. He elaborates for example on the denial of harms as daily practice in factory farms and slaughterhouses, for 'necessity' and concerning recreation, such as hunting and fishing. Narratives are produced by which humans can deny any kind of crime. The revelation of such crimes in turn are prevented by laws designed to stifle exposure of animal cruelty in factory farms by animal rights activists, illustrating, White maintains, that the truth of what happens in the countryside is always subject to contestation, repression and subversion". But is this only the case in the countryside? A further observation is that many of the environmental folk crimes are locally and culturally embedded, such as lobster catching and logging for firewood and construction, which have later been criminalized, but are regarded as mostly legitimate by the population.

The chapter further offers an examination of "poaching" and its various motivations, however much of this could easily and is actually a presentation of the motivation not only for taking and killing animals illegally, but also for the different parts of the chain in wildlife trafficking, whether the offender who takes the animal, the middleman, the trafficker or the buyer/consumer. Like in other kinds of animal abuse, as mentioned above, neutralization techniques are applied to defend the crimes (see Sollund, 2012). When it comes to law enforcement of folk crimes, White exemplifies how this may often be lenient, such as driving 4WD in protected areas of Tasmania, or tree theft in the US. While leniency appears in some crimes, in others, such as rhino and elephant killing for their horns and tusks, punishment can be heavy. But the question is whether these kinds of crimes, that often with without justification are described as being 'organized', funding terrorism, etc. (Runhovde, 2017) can also simultaneously be defined as only 'folk crimes', and whether this is an accurate concept. Rather, 'folk crime' may regarded as an euphemism for a seriously harmful act.

My impression, after studying wildlife crimes and how they are enforced, including in Norway, is not that poor local people suffer because they may no longer continue with their cultural activities and thereby they suffer injustice, which seems to be implicated in the discussion. Rather, I find these crimes are committed to obtain some kind of unnecessary gain, whether economic or other, and are constantly extremely leniently punished, at least in Norway, Colombia, and Brazil. However, White finds that "conservation without acknowledgement of traditional human users, and their systemic contribution to biological diversity and ecological wellbeing, is oppressive and counter-productive" (p.305). An essential point in my view is that with the tremendous expansion of the human species, we need to be more careful than ever in accepting traditional exploitation. My feeling from the chapter is it takes sides a little here and a little there, and I am not sure who wins in the end: Should concern be paid to the animals that are killed, thus to animal rights and species justice, or should concern here be for the people who now illegally but previously legally, kill the animals? I find also chapter is firmly positioned in green criminology. Again it appears that 
it is only the fact that such crimes against animals, as well as how they are denied, often take place in rural locations is what makes this chapter rural criminology, in the context of the book.

\section{Chapter 30: Conservation Crime as Political Protest}

This chapter, written by George Holmes, follows up on White's article about poaching as folk crime, setting the stage with the willful killing of an elephant herd by a local population in Tanzania, however, in this chapter the illegal killing of wildlife is described as a conservation crime. This crime is analysed as an act of protest and is placed together with other protest acts which people may recur to when opposing conservation measures. By placing this wildlife crime in context of broader rural politics and conflicts, particularly classbased struggles over rural livelihoods, alternative rationales for these acts are revealed. For example, conservation measures are made at high political levels, not the local or community, that is, by means of enforcement of international conventions, such as CITES (Convention on International Trade in Endangered Species).

Other forms of crimes involve setting fire which is a crime in which it is hard to pin the offender. The article is a descriptive account of different forms of protest crimes against the environment, including protected, endangered wildlife. It shows for example that people by different measures may still use traps and abuse regulations that are established to protect iconic endangered species, such as elephants and lions, in order to enhance the effect of their protest crime. Towards the end of the chapter comes an interesting layout of the methodological challenges in researching protests as environmental crimes, such as related to hidden motivations and specific cultural traits of the offenders. The chapter is interdisciplinary and provides interesting alternative understandings of wildlife crimes and other environmental crimes. It may be perceived as conservation criminology, as this contribution is taking an anthropocentric approach (Sollund, 2017a). Crimes against animals and setting fires are treated as similar crimes, consequently from a green criminology perspective it lacks the application of theories relating to eco-and species justice like those applied in the previous chapter. This chapter may thus be more rural criminology than green criminology, and perhaps is it not at all criminology, despite investigating motivations people have for committing crimes against the environment and its beings?

\section{Chapter 31 Illegal hunting: between social and criminal justice}

This chapters, written by Erica von Essen, Hans-Peter Hansen, Helena Nordström Källström, M. Nils Peterson and Tarla. R. Peterson, follows in the same track as the two previous chapters, dealing with illegal hunting. Questions they ask on the first page of the chapter (pate 319) are whether the offenders of such crimes are "...common criminals to be deterred through penal sanctions?", or, “...folk criminals to be shown the light through awareness and education?”, or, are they “...dissenters whose crimes partly seek to publicize injustices in wildlife and hunting regulations?" They argue that understanding the nature of illegal hunting is a "vital endeavour for rural criminology given that it represents an emerging 
nexus with green criminology." Because both disciplines are still in their "infancy", they argue that these disciplines are in need of more methodological and theoretical depth at this particular juncture.

Consequently, in this chapter, green criminology and rural criminology are perceived as two sides of the same coin, or perhaps even on the same side of the coin, and the authors do not differentiate between the two sub disciplines. However, by taking a clear anthropocentric approach; e.g. applying wording like 'harvesting' when it comes to the illegal killing of animals, in my view they place themselves more in line with conservation criminology whose research focus is rural crime. The chapter also has a traditional criminological offender/crime approach, which by means of a sophisticated literature review explores how illegal hunting has previously been analyzed, including through instrumental and normative perspectives, in turn including analyses of cost benefit, deterrence and neutralization techniques. The chapter offers an offender typology, detailing the drivers that lead offenders to engage in illegal hunting, including: "recreational satisfaction, thrill killing, trophy hunting, gamesmanship, protection of self and property, profit, consumption, rebellion, as a traditional right, and disagreement with particular game or wildlife regulations. Furthermore, the chapter considers profiling theories, including multiple criteria like motivations, modus operandi and geography.

The authors then turn to illegal hunting as crimes of dissent (which is also the topic of Erica von Essen's Ph.D. thesis in 2016) through which the offenders kill to make a point of protest, also explicated in the previous chapter. The authors criticize what they call the myopic reading of offenders of illegal hunting, claiming that this has led them to be unduly labelled as criminals, rather than conscientious dissenters, hunters have thus been unduly stigmatized and criminalized. Therefore, they argue it is urgent to pay attention to the social justice conditions and the problems of legitimacy that encourage illegal hunting. This could be done by means of dialogical uptake to center on: (1) continuous justification of wildlife regulation and policy by legislating agents, (2) providing dissenting citizens with opportunities for effective contestation of goals behind legislation, and (3) instituting a forum for satisfying the conditions of dialogical reciprocity. The article concludes that:

"Restoring social validity to laws remains the only viable option for a long-term solution to illegal hunting. As a generalized pattern of practices framed by a public discourse on illegal hunting's relative acceptability in response to illegitimate and corrupt governments, the crime has unmistakably become a socio-political practice of dissent that carries with it a critique of current state practices." (p. 325)

However, it is debatable whether restoring (or perhaps rather creating) social validity to norms implying the wrongfulness of killing endangered wolves is possible when and if these animals are cast as enemy, trophies etc. If, for example, the hatred against predators is sufficiently strong, and the hunter offenders feel the basis for the criminalization is unjust due to cultural practices and norms that previously permitted such acts, then such laws are unlikely to ever gain legitimacy among such groups of people, while on the other hand, 
among the majority of the population they might. It is an open question whether dialogue could change the attitudes the offender hunters have against public conservation measures. This is a case in which the power of law and its enforcement could be used to affect the normative climate concerning wildlife protection, rather than seeking legitimacy within the groups that are least likely to abide by these laws. For example, weak law enforcement of such crimes may imply that the offenders regard they have a (relative) accept for these crimes, whether they are committed for instrumental reasons, such as getting a trophy or the also instrumental reason of committing an act of dissent, using the kill to send a message to the authorities.

\section{Chapter 32: Illegal Hunting as Rural Defiance}

This chapter, by Mari Pohja-Mykrä, is yet another contribution to the crimes against wildlife topic, here differentiating between "poaching” with the traditional meaning as theft of wildlife and thereby gaining profit, and illegal hunting which is done for other motives, which in course of the read also here turns out to be in order to defy public conservation efforts to protect endangered species. The chapter opens much like the previous, albeit without positioning itself within rural or green criminology explicitly. Like the previous chapters, it lists literature that has dealt with the so called "folk crimes" of illegal killing of wildlife. The perspective is anthropocentric and similar to the previous in that it implies that some kind of injustice has been done to the offender hunters who cannot any longer kill as they wish; consequences are listed as harmful to ecosystems and species, rather than for the individuals who are killed. It consequently also adopts an anthropocentric conservation criminology perspective. The theoretical approach to illustrate illegal hunting as rural defiance rests on Sherman's defiance theory (1993), based on the following conditions: (1) the offender is alienated from society and authoritative agents; (2) the sanctions are perceived as unfair and stigmatizing; and (3) the offender does not internalize the shame associated with the sanction.

The chapter further gives an historic and geographic account of conservation measures and how they conflict with rural people's interest in killing for their own good. Illegal killing of wolves in Sweden and Finland is designated as an urban-rural conflict, which at least in Norway, is not as straight forward (Skogen et al 2010). Implicitly also this article seems to sympathize with the hunters, rather than their victims, seeing the "crimes of defiance" as legitimate acts of protest against unfair conservation policies which deprive rural people of their traditional customs and rights. Local people living in large carnivore territories are dominated not only by frightening species, but also by management authorities and conservation groups. Conservation efforts that have a detrimental effect on local people's lives in socio-cultural terms violate their civil rights, including their rights to security and property. Consequently, there seems to be no concern for the repopulation of large carnivores after having suffered under extinction policies until the 1970's. This chapter's conclusions are much in line with the previous chapters, that measures must be made to make the offender hunter finding conservation regulation legitimate; this however, raises the same question: how can hunter offenders that see killing as their right be persuaded to respect wildlife and the 
ways in which free animals are protected by means of international conventions and national legislation? It is suggested both research and management actions should prioritize local-level socio-cultural needs and incorporate local people as noteworthy actors in the policy making process instead of seeing them as bystanders who would agree to whatever policies or measures a government offers.

This is precisely what is done in Norway, through the downgrading of the administrative and academic aspects of the State in favor of politician-controlled selection based on county representation - the so-called regional predator boards [Rovviltnemnder]. The predator boards are loosely subordinate to the Ministry of Environment, and this means that regional political bodies in practice are formulating conditions for predators within the overall framework provided by parliament and government and with the assistance of a professional manager apparatus (directorate and county governors Fylkesmenn) that essentially act as secretariats (Sollund 2016). In practice, often the members of these local predator boards are themselves sheep owners and hunters. As mentioned, the boards confirmed their decision to have the before mentioned 47 of the total population of 67 wolves in Norway killed, even family groups living inside designated predator zones who have never taken sheep. Consequently; yes, the state earns legitimacy and huge support among hunters and farmers who want the wolves killed, but the management policy is losing legitimacy among the rest of the population, such as the more than 60,000 persons in Norway who signed a petition to save the wolves. Consequently, contrary to the strong justification for participatory 'natural resource' management suggested by the author, I find in view of the situation in Norway, that farmer/hunter stakeholders here cannot be trusted with this responsibility. The anthropocentric approach and typically conservation approach perceiving animals as exploitable resources, just like in the CITES convention (Sollund 2011), is further evident when the author claims: "Research is needed that addresses how to turn so-called problem species into local common pool resources, and therefore, illegal killing into a potential threat to the common good." Those who are killed are strikingly absent from the discussion. To conclude the exploration of this chapter; the perspective is anthropocentric, the sympathy is with the humans who kill animals illegally; there is no mention or consideration of ecological or species justice. It may be defined as rural conservation criminology, but lacks much of the more widely encompassing ideologies found in much of the green criminology literature.

\section{Chapter 33: Jumping from the Frying Pan into the Fire: A Criminological Study of Forest Fire-setting in Spain}

This chapter, by Rafa Salvador, is the last one in this section, changing focus from the crimes against animals to arson (and indirect crimes to animals and their ecosystems). The author does not make any statement concerning which field he considers this work to be written into, whether green criminology or rural criminology, but says rural crimes in Spain have been overlooked. The chapter is a descriptive account of fire setting in Spain, basically, leaning on statistics, a Greenpeace report and interview data with judges, and state prosecutors. The author starts by giving an introduction to the phenomenon of fire setting to forest in Europe, supposedly according to his sources 500,000 hectares a year. In Spain, only 
$8 \%$ of the fires have natural causes. Salvador proceeds to discuss the unreliability of public crime ciphers, whether from the prosecutorial authorities or the police. Concerning forest fires there are large dark figures because often they are not reported, hence not perceived of as crime.

Concerning the motivations for fire setting, it is often the "elimination of brushwork and agricultural residues" and "regeneration of pastureland". Wildland arson is mainly a crime committed by farmers or individuals living in rural settings. The chapter further provides an overview of sentencing of forest fires in different districts from 1996-2005 in all Spain showing there were in total (only) 177 condemnatory sentences. From 2008-2012 there were in total 138 condemnatory sentences. The increase in sentencing, interestingly, is in accordance with findings in the EFFACE project, a project funded by the European Commission that ran for 40 months (from 2012-2016) and involved several case studies of different forms of environmental crimes. In Europe, fighting environmental crime is based on the establishment of specialist environmental judges. An emphasis on environmental crimes based on improvement of how these crimes are registered, and thus, their traceability.

Another finding is that criminal sentences that punish state-corporate offenders is very rare. Of the 186 forest arson criminal sentences that were identified between 2008 and 2012, only 12 resulted in corporations receiving monetary fines. Consequently, there is a lack of a deterrent effect and also possibilities for citizens to seek redress for harms committed because of the fires. Salvador states that the use of land is contested, and because it is contested, issues of justice and fairness inevitably arise. Often, the rural people who have lived there for generations are the ones losing out to corporate and state interests. There is an environmental rights concern present in the chapter, as this is often discussed within green criminology (e.g. in Brisman et al.'s chapter in this handbook). Nonetheless, forest fires are also a concern from an ecological justice and species justice perspective, as the ecosystems forming the forests and those living there unavoidably must be harmed. These are not mentioned either, and do remain hidden victims. The chapter could have gained from a less descriptive, more analytical approach.

\section{Conclusion: Green criminology and rural criminology are sleeping together and could develop their relationship}

To sum up the exploration of these chapters and the green -rural criminology relationship. I find the chapters consist basically of analyses of crimes taking place in rural areas, against the environment and non-human animals. I am in doubt whether such sociogeographic location is sufficient as a defining factor concerning what is rural criminology, or what is the intersection between rural and green criminology. Avi Brisman, Nigel South, Bill McClanaham and Rob White seem to try to free themselves from their green criminology baggage but do not quite succeed, so these papers could more easily have been adapted into any green criminology anthology. The other chapters typically reflect conservation, or perhaps, conventional critical criminology, in that there is an anthropocentric approach to 
ways in which humans are wronged, even when they are the wrongdoers. This may be a more typical feature of rural criminology, than of green criminology? Donnermeyer says, for example, when summing up lessons in chapter 42 that the norms of a community, by leading to selective enforcement practices, can mask some types of crime, such as poaching and various types of abuse and violence within families. This contention, however, implies that "poaching" - defined as the illegal killing or taking of wildlife - is not abuse or violence, it is merely a form of rural crime (read theft). In that context it makes sense to focus on human offenders, rather than on their animal and ecosystem victims.

Perhaps, trying to specifically identify whether or not a scholarly contribution is green or rural criminology is pointless, the point rather being that, as stated by Avi Brisman (2014, p. 27): "Disciplinary borders should have little bearing on our attempts to identify, analyze, understand and confront environmental harms."

I therefore very much welcome this handbook and its inclusion of environmental problems. I still observe that, perhaps, rural criminology could benefit from applying more holistic harm - and cross disciplinary approaches, and rural criminology could support green criminology to diverge attention from the traditional crime focus of conventional criminology to take an interest in wider social practices and their harmful effects, whether these take place in urban or rural areas, against humans or nonhumans. I consequently think the relationship between green and rural criminology may be mutually beneficial.

\section{References}

Beirne, P., \& South, N. (Eds.). (2013). Issues in green criminology. Routledge. https://doi.org/10.4324/9781843926344

Beirne, P. (2014). Theriocide: Naming Animal Killing. International Journal for Crime, Justice and Social Democracy, 3(2), 50-67. https://doi.org/10.5204/ijcjsd.v3i2.174

Beirne, P. (1999). For a nonspeciesist criminology: animal abuse as an object of study. Criminology, 37(1), 117-148. https://doi.org/10.1111/j.1745-9125.1999.tb00481.x

Brisman, A. (2014). Of Theory and Meaning in Green Criminology. International Journal for Crime, Justice \& Social Democracy, 3(2), 21-34. https://doi.org/10.5204/ijcjsd.v3i2.173

Bye, L. M. (2003). Masculinity and rurality at play in stories about hunting. Norsk Geografisk Tidsskrift-Norwegian Journal of Geography, 57(3), 145-153. https://doi.org/10.1080/00291950310002125

Christie, N. (1975). Hvor tett et samfunn?: [How densely knit a society?] Oslo: Universitetsforlaget. 
Ellefsen, R., Sollund, R. and G. Larsen (Eds.) (2012). Eco-global crimes: contemporary problems and future challenges. Ashgate.

Hallsworth, S. (2008). Imaginary spaces and real relations. In Sollund, R. (Ed). Global harms: ecological crime and speciesism (pp. 71-87). Nova.

Nibert, D. (2002). Animal rights/human rights: Entanglements of oppression and liberation. Rowman \& Littlefield Publishers.

Nibert, D. (2013). Animal oppression and human violence: domesecration, capitalism, and global conflict. Columbia University Press.

Runhovde, S (2017). Disarming the 'war' on wildlife crime. Critical Criminology, 25, 275291. https://doi.org/10.1007/s10612-017-9360-0

Skogen, K., Figari, H. and Krang, O. (2010). Meninger om rovviltforvaltning. Erfaringer fra tre kommuner på Østlandet. NINA rapport 607. Accessed on January 7, 2017, at http://www.nina.no/archive/nina/PppBasePdf/rapport/2010/607.pdf

Sollund, R. (2008). Causes for speciesism: Difference, distance and denial. In Sollund, R. (ed). Global Harms: Ecological Crime and Speciesism. New York: Nova Science Publishers, 109-131.

Sollund, R. (2012). Speciesism as toxic practice versus valuing difference and plurality. In Ellefsen, R., Sollund, R., \& Larsen, G. (Eds.), Eco-global crime: contemporary problems and future challenges (pp. 91-114). Ashgate.

Sollund, R. (2015). With or without a license to kill: Human-predator conflicts and theriocide in Norway. In Brisman, A., South, N. and White, R. (Eds.) Environmental Crime and Social Conflict: Contemporary and Emerging Issues (pp. 95-124). Ashgate.

Sollund, R. (2017a). Doing green, critical criminology from an auto-ethnographic, feminist approach. Critical Criminology, 25, 245-260. https://doi.org/10.1007/s10612-017-9361$\mathrm{z}$

Sollund, R. (2017b). Perceptions and law enforcement of illegal and legal wolf killing in Norway: organised crime - or folk crime? Palgrave Communications, 3. https://doi.org/10.1057/palcomms.2017.59

Stretesky, P. B., \& Lynch, M. J. (2014). Exploring green criminology: Toward a green criminological revolution. Ashgate Publishing, Ltd..

Stretesky, P. B., Long, M. A., \& Lynch, M. J. (2013). The treadmill of crime: Political economy and green criminology. Routledge. https://doi.org/10.4324/9780203077092 
von Essen, E. (2016). In the gap between legality and legitimacy: illegal hunting in Sweden as a crime of dissent. Swedish University of Agricultural Sciences. Accessed on February $6^{\text {th }}, 2017$ from http://pub.epsilon.slu.se/13567/

White, R. (2002). Environmental harm and the political economy of consumption. Social Justice, 29(1/2), 82-102. https://doi.org/10.4324/9781315880723

White, R. (2011). Transnational environmental crime: Toward an eco-global criminology. Routledge.

White, R. (2013). Crimes against nature: Environmental criminology and ecological justice. Routledge.

Wyatt, T. (2014). A criminological exploration of the industrialisation of pig farming. Internet Journal of Criminology, 1, 12-28. 